\title{
Noteworthy orbital-craniocerebral trauma
}

\section{Figure Penetrating trauma to the brain through orbit}
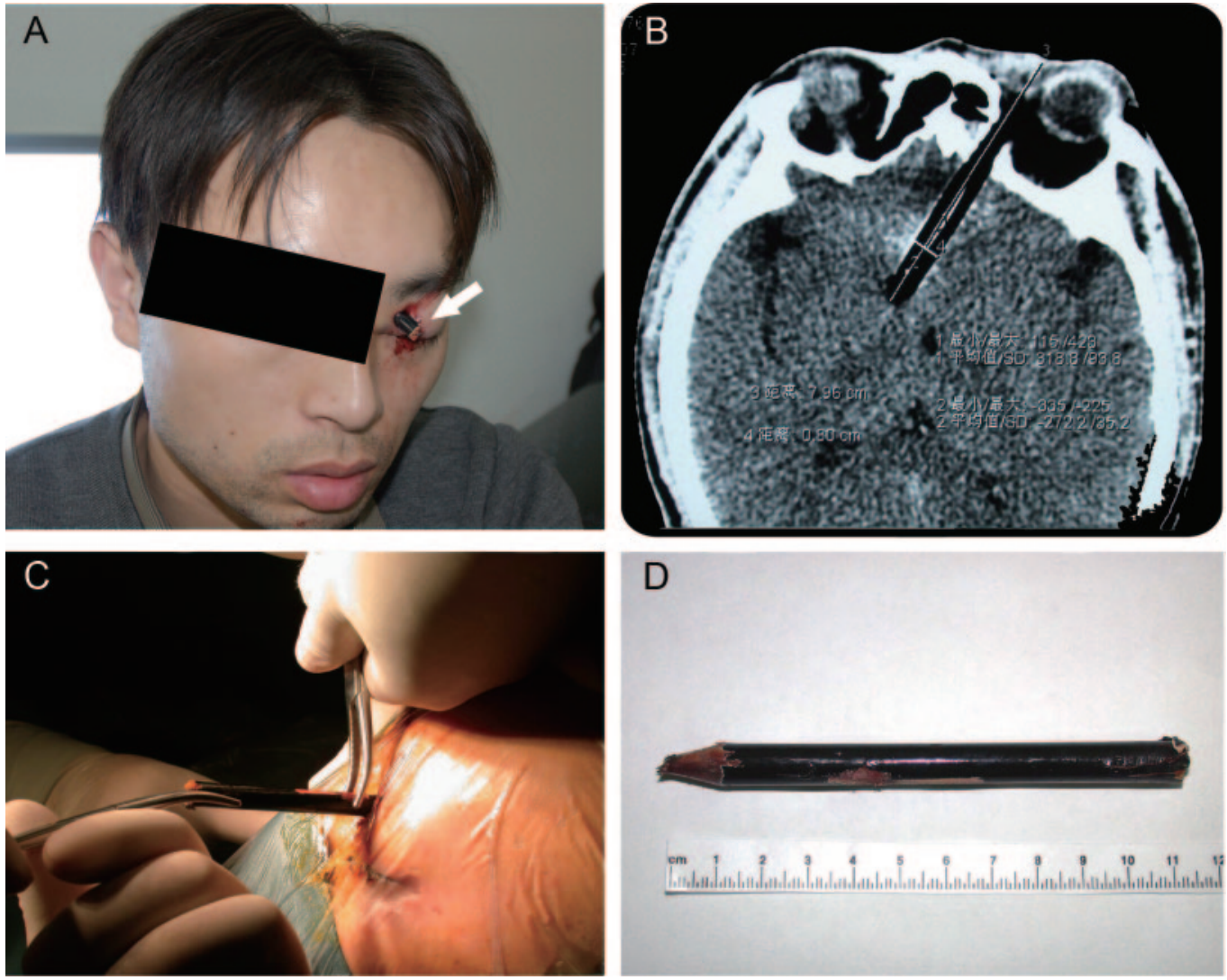

(A) Clinical photograph of the injured patient. Arrow indicates the outside portion of the pencil. (B) CT showing the pencil penetrating into the brain through left orbit. (C, D) The pencil was removed surgically.

A 31-year-old man presented 6 hours after sustaining a penetrating injury of his left orbit with an 11.5centimeter pencil, with 1.6 centimeters left outside (figure, A, arrow). Neurologic deficits were not observed. CT showed the pencil penetrated into the inferior frontal lobe through the orbital roof, without injury to the eyeball. Ten centimeters of the pencil was located in the orbital and intracranial cavity, with 6 centimeters in the brain tissue, with scant accompanying hemorrhage (figure, B). Emergency surgery loosened and removed the whole pencil (figure, $\mathrm{C}$ and $\mathrm{D}$ ), after which the patient had a satisfactory recovery.

Xiang Zhang, MD, PhD, Xinggang Mao, MD, PhD, Wei Zhang, MD, PhD, and Jianning Zhang, $M D$, PhD, Shaanxi, China

Author contributions: Dr. X. Zhang: design of the study \& writing. Dr. Mao: interpretation of the data and writing. Dr. W. Zhang: drafting the manuscript. Dr. J. Zhang: revising the manuscript.

Disclosure: The authors report no disclosures.

Correspondence \& reprint requests to Dr. Zhang: xzhang@fmmu.edu.cn 


\title{
Neurology
}

\author{
Noteworthy orbital-craniocerebral trauma \\ Xiang Zhang, Xinggang Mao, Wei Zhang, et al. \\ Neurology 2012;78;1104 \\ DOI 10.1212/WNL.0b013e31824e8fa2
}

\section{This information is current as of April 2, 2012}

\section{Updated Information \& Services}

Subspecialty Collections

Permissions \& Licensing

Reprints including high resolution figures, can be found at: http://n.neurology.org/content/78/14/1104.full

This article, along with others on similar topics, appears in the following collection(s):

\section{Brain trauma}

http://n.neurology.org/cgi/collection/brain_trauma

Critical care

http://n.neurology.org/cgi/collection/critical_care

CT

http://n.neurology.org/cgi/collection/ct

Orbit

http://n.neurology.org/cgi/collection/orbit

Information about reproducing this article in parts (figures,tables) or in its entirety can be found online at:

http://www.neurology.org/about/about_the_journal\#permissions

Information about ordering reprints can be found online:

http://n.neurology.org/subscribers/advertise

Neurology ${ }^{\circledR}$ is the official journal of the American Academy of Neurology. Published continuously since 1951, it is now a weekly with 48 issues per year. Copyright Copyright (? 2012 by AAN Enterprises, Inc.. All rights reserved. Print ISSN: 0028-3878. Online ISSN: 1526-632X.

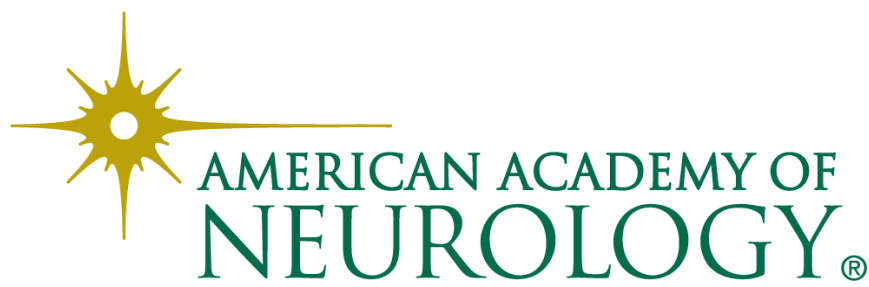

